\title{
'Fishing' Out a Long Distance Regulator of the Sonic Hedgehog Gene Associated With Preaxial Polydactyly
}

\begin{abstract}
A review of: Lettice LA, Heaney SJH, Purdie LA, Li L, de Beer P, Oostra BA, Goode D, Elgar G, Hill RE, de Graaf E 2003 A long-range $S h h$ enhancer regulates expression in the developing limb and fin and is associated with preaxial polydactyly. Hum Mol Genet 12:1725-1735
\end{abstract}

$\mathrm{P}$ REAXIal POLYDACTyLy [PPD (OMIM 190605)] is a commonly observed congenital limb malformation that usually involves duplication of the thumb, index finger, or various forms of triphalangeal thumbs. Most cases of PPD show an autosomal-dominant mode of inheritance although sporadic cases have been described. Previous work based on genetic analysis on affected families mapped the PPD disease locus to a region in the q36 band of the human chromosome 7 encompassing the Sonic hedgehog $(\mathrm{SHH})$ gene. Mutations and deletions of $\mathrm{SHH}$ have previously been shown to cause holoprosencephaly (1).

In the developing limb, experiments using chick explants and mouse models showed that proper spatio-temporal expression of Shh in the zone of polarizing activity (ZPA) is crucial for the anterio-posterior patterning of digits (2). Several mouse mutants displaying preaxial polydactylous phenotypes are caused by the mis-expression of Shh in the ectopic anterior margin at early limb bud stages. Previously, Lettice and colleagues studied a mutant Sasquatch and found evidence that a cis-regulator of Shh was likely located within the Lmbr1 gene about 1 million base pairs $(\mathrm{Mb})$ upstream from the start of the Shh gene (3).

Comparing genome sequence between human and an evolutionarily distant species, such as mouse, in search of highly conserved DNA segments is a powerful way to help identify functional elements in the genome. In their recent study, Lettice and colleagues used this approach to look for a candidate regulatory element for $S h h$

\section{Joseph Cheung}

(4). They compared the genomic sequence of human, mouse, chicken, and pufferfish, and identified a 400 bp region located in intron 5 of Lmbrl that is highly conserved between all four species. To test whether this domain regulates gene activity reminiscent of limb Shh expression in the ZPA, the authors incorporated the mouse conserved DNA segment into transgenic constructs. Their transgenic embryos showed that the reporter gene was indeed driven to express in the posterior margin of both the fore and hindlimbs similar to the endogenous Shh activity. They refer to this conserved functional element as the ZPA regulatory sequence, ZRS.

Next, Lettice and colleagues examined families with PPD to see if they could identify mutations within the ZRS domain. These affected families were previously screened for mutations in the SHH and LMBRl genes but none were found. This time, in a large family of Dutch background, the authors found a heterozygous $\mathrm{C} / \mathrm{G}$ transversion within the ZRS of the human sequence in all 96 affected individuals, while 117 unaffected individuals in this family as well as 1354 control chromosomes were tested to have a homozygous $\mathrm{C} / \mathrm{C}$. Three additional single nucleotide alterations were identified from three other PPD families (two Belgian, one Cuban) while proper controls were shown to lack these alterations. Furthermore, in a mouse mutant the hemimelic extra toes, they also found another nucleotide change in the mouse ZRS sequence. Hence, these base pair changes that occurred at highly conserved nucleotides within the ZRS are suggested to be pathogenic mutations leading to the PPD phenotype.

It is truly remarkable that a single nucleotide mutation in a regulatory element is capable of modifying the activity of its target gene $1 \mathrm{Mb}$ away. Moreover, this key regulator appears to specifically control the Shh gene promoter without acting on any surrounding genes. The authors further noted that a broad conservation of genomic synteny is present among vertebrates (including pufferfish) in and around the Shh locus, supporting that the transcription control for Shh likely evolved prior to the fin-to-limb transition in early vertebrate evolution and that such genetic configuration has been preserved since that time. Further experiments underway to pinpoint which gene products interact with the DNA motifs within the ZRS should illuminate the intricate control of the ZPA establishment towards limb development. It is also noteworthy that studies of holoprosencephaly patients with non-gene translocation breakpoints suggest there are still to be identified brain-specific regulatory elements upstream of the gene (5).

Clearly, non-coding mutations and regulatory polymorphisms that affect gene transcription are difficult to pinpoint among the sea of single nucleotide polymorphisms found in the human population. However, their contribution to developmental disorders as well as other complex traits is likely to be substantial and has so far been largely neglected. Recent avail- 
ability of the mouse and pufferfish genome sequences makes large-scale comparative analysis now possible. Ongoing comparative sequencing projects targeting a diverse collection of vertebrate species (6) will be a great resource for studying regulatory genetics and human disease.

1. Roessler E, Belloni E, Gaudenz K, Jay P, Berta P, Scherer SW, Tsui LC, Muenke M 1996 Mutations in the human Sonic Hedgehog gene cause holoprosencephaly. Nat Genet 3:357-360

2. Riddle RD, Johnson RL, Laufer E, Tabin C 1993 Sonic hedgehog mediates the polarizing activity of the ZPA. Cell 75:1401-1416

3. Lettice LA, Horikoshi T, Heaney SJ, van Baren MJ, van der Linde HC, Breedveld GJ, Joosse M, Akarsu $N$, Oostra BA, Endo N, Shibata M, Suzuki M, Takahashi E, Shinka T, Nakahori Y, Ayusawa D,
Nakabayashi K, Scherer SW, Heutink P, Hill RE, Noji S 2002 Disruption of a long-range cis-acting regulator for $S h$ causes preaxial polydactyly. Proc Natl Acad Sci USA 99:7548-7553

4. Lettice LA, Heaney SJH, Purdie LA, Li L, de Beer P, Oostra BA, Goode D, Elgar G, Hill RE, de Graaf E. 2003. A long-range $S h h$ enhancer regulates expression in the developing limb and fin and is associated with preaxial polydactyly. Hum Mol Genet $12: 1725-1735$

5. Belloni E, Muenke M, Roessler E, Traverso G, Siegel-Bartelt J, Frumkin A, Mitchell HF, DonisKeller H, Helms C, Hing AV, Heng HH, Koop B, Martindale D, Rommens JM, Tsui LC, Scherer SW 1996 Identification of Sonic hedgehog as a candidate gene responsible for holoprosencephaly. Nat Genet 3:353-356

6. Thomas JW, Touchman JW, Blakesley RW, Bouffard GG, Beckstrom-Sternberg SM, Margulies EH, Blanchette M, Siepel AC, Thomas PJ, McDowell JC, Maskeri B, Hansen NF, Schwartz MS, Weber RJ, Kent WJ, Karolchik D, Bruen TC, Bevan R, Cutler DJ, Schwartz S, Elnitski L, Idol JR, Prasad AB, Lee-Lin SQ, Maduro VV, Summers TJ, Portnoy
ME, Dietrich NL, Akhter N, Ayele K, Benjamin B, Cariaga K, Brinkley CP, Brooks SY, Granite S, Guan X, Gupta J, Haghighi P, Ho SL, Huang MC, Karlins E, Laric PL, Legaspi R, Lim MJ, Maduro QL, Masiello CA, Mastrian SD, McCloskey JC, Pearson R, Stantripop S, Tiongson EE, Tran JT, Tsurgeon C, Vogt JL, Walker MA, Wetherby KD, Wiggins LS, Young AC, Zhang LH, Osoegawa K, Zhu B, Zhao B, Shu CL, De Jong PJ, Lawrence CE, Smit AF, Chakravarti A, Haussler D, Green P, Miller W, Green ED 2003 Comparative analyses of multi-species sequences from targeted genomic regions. Nature 424:788-793

Program in Genetics and Genomic Biology The Hospital for Sick Children

555 University Avenue

Toronto, Ontario M5G 1 X8 Canada joe@genet.sickkids.on.ca

DOI: 10.1203/01.PDR.0000096649.17556.E2 